Sabina Kwak

\title{
Etykiet(k)a wielkiego miasta O seksualizacji przestrzeni, utowarowieniu relacji międzyludzkich i regułach damsko-męskich gier w nowoczesnym i ponowoczesnym mieście
}

Ostatnie dekady XIX wieku to czas postępującej urbanizacji, będącej konsekwencją tzw. drugiej rewolucji przemysłowej. Olbrzymie tempo życia, jakie staje się wówczas normą, sprzyja zmniejszeniu dystansu między jednostką a masą - człowiek miejski musi stać się „,człowiekiem tłumu”, kimś, kto jest - używając terminologii Guy Deborda - członkiem „społeczeństwa spektaklu” - żyje w skupisku, pozostaje jednak anonimowy, uczy się pa tr z eć na innych obcych i czytać z ich fasad.

$\mathrm{Na}$ wykształcenie tych umiejętności wpływa pojawienie się pasażu - przestrzeni, o której w ilustrowanym przewodniku po Paryżu z roku 1852 pisze się jako o „mieście, ba, świecie na niewielką skalę" [Benjamin 1996: 364]. Zgodnie ze słowami Zygmunta Baumana Walter Benjamin obiera nawet paryskie Arkady - „ciągi eleganckich sklepów wabiących ponętnymi witrynami zamożnych mieszkańców stolicy, pokryte dachami, aby uniezależnić wizyty od kaprysów pogody - za prototyp wybiegu, jakie miasto nowoczesne oferuje

1 Spektakl nie jest u Deborda zwykłym nagromadzeniem obrazów, ale zapośredniczonym przez obrazy stosunkiem społecznym między osobami, którego przyczyny leżą w autokratycznym władztwie gospodarki towarowej [Debord 2006]. 
spacerowiczom" [Bauman 1994: 23]. W przestrzeni tej - jego zdaniem - lęgną się wzory zachowań, które staną się typowe dla życia w nowoczesnym mieście:

spacerowicz uczy się traktować świat jako teatr, ulicę jako scenę, przechodniów jako aktorów mimo woli, siebie jako reżysera sztuk bez prologów i rozwiązań, a życie jako grę, w której nikt nie jest tym, kim się być zdaje, w której każdego można postrzegać na różne sposoby i w której różnice między prawdą, udawaniem i domysłem zacierają się - ale też są nieistotne i nikogo szczególnie nie frapują ani trapią [Bauman 1994: 23].

Uczestnictwo w tym „pasażowym widowisku” z biegiem czasu staje się coraz bardziej popularne. Bauman pisze, że dzieje się tak za sprawą producentów i sprzedawców towarów, którzy dostrzegli w zamiłowaniach spacerowicza własną szansę:

jeśli tylko deptaki miejskie okoli się sklepami wystawiającymi towary dostępne dla „zwykłych ludzi” [...], „zwykły człowiek” będzie mógł zakosztować przyjemności spacerowicza i nie omieszka tego uczynić. Możliwości dla handlu odkryją się ogromne. To nie potrzeby będą sprowadzać klienta do sklepu, lecz znacznie bardziej od potrzeb chłonne i rozciągliwe pragnienia estetyczne. Klienci powalą masowo, i nie po to tylko, by „załatwić sprawę i pożegnać”, ale by nakarmić do woli oczy widowiskiem, czyniąc to, sami staną się widowiskiem dla siebie nawzajem, niepłatnymi aktorami niekończącego się przedstawienia, atrakcją, jaka sama siebie przyciąga [Bauman 1994: 24].

Typowo miejski wynalazek - „promenada nabywców” - staje się zatem areną prezentacji dwojako rozumianych towarów (ludzi i rzeczy), „idealnym terenem myśliwskim dla łowców wrażeń, poszukiwaczy czysto estetycznego, niezmąconego przez inne kłopoty zaspokojenia” [Bauman 1997: 153]. Jak pisze Bauman, „człowiek w sferze publicznej staje się eksponatem, wabiącym i nęcącym swym powabem, ale niczego nie obiecującym i do niczego nie zobowiązującym" [Bauman 1997: 154].

Ludzka „powierzchnia reklamowa” zyskuje na atrakcyjności na przykład poprzez modę i makijaż. Zdaniem Charlesa Baudelaire’a 
używanie tych środków bierze się z upodobania do ideału, który w umyśle ludzkim góruje nad wszystkim, co życie naturalne gromadzi w nim przyziemnego i plugawego - jest wzniosłą deformacją natury, ciągłą i nieustającą próbą jej poprawienia [Baudelaire 1998: 56]. „To nic, że o podstępie i sztuczności wiedzą wszyscy, jeśli sukces jest pewny i efekt nieodparty" [Baudelaire 1998: 56] - czytamy w eseju Malarz życia nowoczesnego. Przekonanie to, sformułowane w drugiej połowie XIX wieku, jest aktualne aż do dziś, z tą różnicą, że „niewinne" środki, o których wspomina Baudelaire, można by rozszerzyć o operacje plastyczne i fenomen Photoshopa - wszakże chodzi o to, by „ludzkie opakowanie” prezentowało się jak najlepiej. Projektowanie swojego wizerunku przez zastosowanie dostępnych środków wzmacnia poczucie własnej atrakcyjności, dodaje pewności siebie, umożliwia pokazanie (uwypuklenie) tej części nas samych, którą mamy ochotę zaprezentować w miejskim widowisku; pozwala poczuć, że „ja” pasuję do siebie - obraz zewnętrzny koresponduje z tym, jak się czuję lub chciałbym/chciałabym się czuć2.

Demonstrowane na ulicy (w pasażu) „opakowanie” ma więc olbrzymie znaczenie - jest przekazem, kodem, informacją i, co najważniejsze, nie jest przypadkiem, darem natury, lecz świadomym wyborem. W sytuacji, gdy relacje międzyludzkie cechuje naskórkowość,

2 Do podobnych wniosków dochodzą autorzy książki Psychoanaliza garderoby: „Ubranie jest swego rodzaju „drugą skórą, na której odciskają się emocje i uczucia. Obraz zewnętrzny i wewnętrzny nakładają się na siebie i wzajemnie na siebie oddziałują. Właśnie dlatego to samo ubranie może się nam wydawać inne w zależności od tego, czy wisi w szafie, czy też mamy je na sobie. Na naszym ciele przybiera ono barwę naszego humoru - smutku, zmęczenia lub radości. [...] Strój reprezentuje przestrzeń, w której ja pragnie się odnaleźć i uchwycić jakąś część siebie, która mu umyka. »Obdarta ze skóry « kobieta próbuje w nowym ubraniu znaleźć powłokę, która ją na nowo określi w jej własnych oczach. [...] Ubranie przychodzi jej z pomocą w stworzeniu wyimaginowanej przestrzeni koniecznej dla odbudowania własnego ja - ja, które wciąż się zmienia i zawsze pozostaje w ruchu" [Joubert, Stern 2006: 68-70]. 
krótkotrwałość i powierzchowność ${ }^{3}$, umiejętność szybkiego nadawania i odbierania tych zewnętrznych sygnałów (ich interpretacja) jest niebywale istotna, oznacza bowiem możliwość dotarcia do „chwilowej tożsamości” podmiotu, stworzenia iluzji wiedzy „o kimś”, kto dzięki konsumenckiej wolności wyboru używa pewnego wizerunku przez określony czas. Życie miejskie daje możliwość „przymierzania” i odrzucania kolejnych tożsamości.

Kluczem do zrozumienia tego zjawiska jest pojęcie sex appealu, oznaczającego w najprostszym rozumieniu atrakcyjność erotyczną. Rzeczownik appeal tłumaczymy jednak także jako „apelację”, „wezwanie”, „urok”, „odwołanie się do czegoś”, „przemawianie (do kogoś)”, „wzywanie kogoś do zrobienia czegoś”. Sex appeal można by więc zdefiniować jako „objawienie seksualności”; byłby to sposób przemawiania do kogoś, odwoływania się do jego czysto popędowej strony, wezwanie do seksu. W ponowoczesnym mieście sex appeal objawia się na poziomie etykietki.

W najbardziej znanym obrazie pokazującym seksualizację miejskiego życia, w serialu Seks $w$ wielkim mieście, powiązanie erotyki z obsesją na punkcie znanych marek jest symptomatyczne. Nie chodzi tu

3 Bauman pisze: „Obcy spotykają się jako obcy i jako obcy się rozstają, gdy przypadkowe spotkanie kończy się - równie nagle, jak nagle się zaczęło. Obcy spotykają się tak, jak przystało na obcych. Ich spotkania nie przypominają w niczym spotkań krewnych, przyjaciół lub znajomych. Są to niby-spotkania. Obcy nie nawiązują do wcześniej poruszanych tematów, nie informują się o troskach i radościach, których doświadczyli od »zeszłego razu «, nie odwołują się do wspólnych wspomnień. Stoją naprzeciw siebie, nie wiedząc, na czym się oprzeć i czym się kierować. Spotkanie obcych jest zdarzeniem bez przeszłości. Z reguły bywa także zdarzeniem bez przyszłości (wolnym, w miarę możliwości, od przyszłych zobowiązań), historią, w której »ciąg dalszy nie nastąpi «, produktem jednorazowego użytku, który należy spożyć na miejscu - w całości, niezwłocznie i bez odkładania na później. Jak pająk, który cały swój świat buduje z nici wysnutej z własnego wnętrza, tak obcy, spotkawszy się ze sobą, mogą liczyć jedynie na to, co uda im się upleść z cienkiej i wątłej przędzy własnych spojrzeń, słów i gestów. Podczas spotkania nie ma miejsca na próby i pomyłki, uczenie się na błędach i liczenie na następną okazję" [Bauman 2006: 147]. 
tylko o kompulsywne zakupy, którym bohaterki często oddają się po rozczarowaniach wynikających z nieudanych związków, lecz o nawiązywanie relacji damsko-męskich na wzór tych konsumenckich.

W jednej ze scen sezonu drugiego ${ }^{4}$ obserwujemy wychodzącą na ulicę Samanthę Jones. Ma na sobie seksowną, czerwoną sukienkę, jej usta są krwistoczerwone. $\mathrm{Z}$ przeciwka nadciąga przystojny, dobrze zbudowany mężczyzna w bordowym krawacie. Ich spojrzenia krzyżują się, ona lustruje jego, on ją, mijają się. Samantha zatrzymuje się przed witryną butiku Prady, on do niej podchodzi i mówi: „Muszę przyznać, że wyglądasz cudownie”. Następnie zaprasza ją na kolację, ona pyta: „Skąd wiesz, że miałabym na to ochotę?”, on odpowiada: „Widziałem, jak na mnie patrzyłaś”. Plan oddala się, widzimy odchodzącego mężczyznę, torebki na wystawie Prady i Samanthę.

Scena zostaje sfilmowana $\mathrm{z}$ perspektywy sklepowej wystawy (kamera pokazuje towary i ludzi niejako w jednym planie; witryna jest ramą dla całego zajścia). My, widzowie, zostajemy tu ulokowani w funkcji obserwatorów. Można powiedzieć, że przyjmujemy pozycję analogiczną do tej, którą zajmuje narrator w opowiadaniu Edgara Alana Poego Człowiek tłumu. Czytamy tam: „Z cygarem w ustach i jakimś dziennikiem na kolanach spędziłem znaczą część popołudnia bądź to zgłębiając się w ogłoszeniach, bądź też przypatrując się mieszanemu towarzystwu, co zapełniało kawiarnię, lub wreszcie wyglądając przez zamglone szyby na ulicę”, aż ostatecznie „skupiłem całą swą baczność na widownię uliczną" [Poe 1989: 47]. Zastąpienie kawiarnianej szyby ekranem telewizora, zza którego obserwujemy całe zajście - być może również w zaciszu domowym wyposażeni w cygara i gazety - czyni nas ponowoczesnymi voyerami. Dochodzi tutaj do przejęcia przez ekran telewizyjny, umieszczony wewnątrz prywatnego mieszkania, funkcji, jakie pełnił teren miejski na zewnątrz domu [Bauman 1994: 25]. To właśnie ten ekran - pisze Henning Bech, duński socjolog, „staje się głównym, najczęściej i najchętniej uczęszczanym wybiegiem

${ }^{4}$ Seks $w$ wielkim mieście, sezon 2, odc. 18, minuty: 6:28-7:52 [1999], reż. D. Starr. 
ponowoczesnego spacerowicza"5. Telewizja (i Internet) są więc najaktualniejszym wariantem pasażu, a ponowoczesne miasto to $\mathrm{w}$ istocie - używając pojęcia Becha - telemiasto.

Widz przyjmuje w tej sytuacji pozycję kogoś, kto nie tylko kupuje serwowany mu przekaz (ponosząc koszty odbioru serialu), lecz także osoby, która, udając się w swój wirtualny spacer, zrównuje wizualnie ludzi i przedmioty umieszczone w witrynie. Relacja między mężczyzną a kobietą zostaje tym samym utowarowiona. Przeglądająca się w szybie wystawowej Samantha jest niczym ekskluzywny produkt kompatybilny z innym ekskluzywnym produktem (mężczyzną) i marką (Prada). Obydwa „towary” (mężczyzna i kobieta) błyskawicznie odczytują swoje etykietki - czerwone sukienka i usta uzupełniają się z barwą krawata.

Bezpośredniość waginalnych (usta) i fallicznych (krawat) sygnałów nie pozostawia tu złudzeń: w tej relacji chodzi o seks (ja - jako widz - też natychmiast etykietuję). Symbolizujące erotyczną gotowość czerwone rekwizyty zostają (przeze mnie i przez bohaterów) zdekodowane. Wzajemne „rozpoznanie się” postaci pokazuje przytoczony wcześniej dialog, bazujący na jednym tylko zmyśle: wzroku. Jak pisze Georg Simmel, przewaga aktywności wzroku nad aktywnością słuchu jest cechą charakterystyczną kontaktów międzyludzkich w wielkich miastach. Główną tego przyczyną, jak wyjaśnia, są publiczne środki komunikacji. „Zanim nie rozpoczęto w XIX wieku produkować autobusów, pociągów i tramwajów, ludzie nie byli zmuszeni przypatrywać się sobie przez długie minuty czy nawet godziny, nie rozmawiając przy tym ze sobą" [Simmel 1975: 513]. Umiejętność powierzchownego patrzenia jest więc jedną z typowo miejskich zdolności adaptacyjnych, wykorzystywanych także w przestrzeni pasażu. Spojrzenie ślizgające się po powierzchni „towaru” (bez konieczności wnikania w jego „autentyczność"), interpretacja etykiet, szybki kontakt - oto prawdziwie miejski sex appeal! Benjamin pisze żartobliwie, że taki dar odczytywa-

5 Bech rozwija koncepcję telemiasta (telecity) m.in. w artykule Citysex. Representing Lust in Public [Featherstone 1999: 215-243]. Wspomina o niej ogólnikowo Bauman [Bauman 1994: 25]. 
nia przechodnia jest umiejętnością, którą „wróżki dają mieszkańcom wielkich miast do kołyski” [Benjamin 1996: 367].

Czerwona sukienka Samanthy przemawia do wyobraźni przechodnia (widza), jej karminowe usta apelują do jego (ich?) zmysłu wzroku, wzywają do działania. Prześliźnięcie się spojrzenia kobiety po linii krawata (z góry na dół i z powrotem) jest objawem podjęcia erotycznej gry, która nie jest jednak zupełnie pozbawiona reguł.

Samantha, po ominięciu mężczyzny, nie idzie bowiem dalej, tylko przegląda się w szybie i czeka na jego dalsze kroki; on przejmuje inicjatywę, komplementuje ją, przechodzi do propozycji spotkania; ona, pomimo wyraźnego zainteresowania, nie godzi się od razu (mówi: „jeszcze nie wiem”, uśmiechając się; „pomyślę o tym”, lekko przytakując). Za szybka zgoda może „spłoszyć zwierzynę”, dlatego należy dać nadzieję, ale zbyt pochopnie jej nie zaspokajać - tylko tym sposobem popyt wzrośnie.

Mamy tu do czynienia z sytuacją, w której stosunki międzyludzkie zostają sprowadzone do modelu konsumpcyjnego. Miejski podryw nie różni się niczym od robienia zakupów - już dama z okresu Drugiego Cesarstwa, jak zaświadcza Benjamin, nie mówi: „kocham go”, lecz „mam na niego kaprys” [Benjamin 2005: 556]. Uwspółcześnioną wersją tego modelu jest sytuacja przedstawiona przez Cindy Lu, autorkę książki The Four Man Plan, która komentując tzw. nowojorski styl randkowania, powiedziała nawet, że umawianie się z różnymi partnerami - niekoniecznie w typie, który najbardziej nam się podoba - pozwala się przekonać, „co nowego jest w ofercie, zanim zdecydujemy się na »zakup « Tego Jedynego" [Windsor, Millar 2010], a równoczesne „posiadanie” wielu mężczyzn jest tym samym, co posiadanie w swojej szafie wielu par obuwia - w końcu nigdy nie wiemy, co będzie nam pasować na daną okazję...

Takie działanie, choć wydaje się liberalne, w gruncie rzeczy jest bardzo restrykcyjne - zakłada opanowanie umiejętności pokazania siebie (swojej powierzchni) przy jednoczesnym zablokowaniu dostępu do sfery prywatnej. „Ponieważ nie sposób znaleźć samopotwierdzenia we własnym istnieniu, pozostaje jedynie pokazać siebie. [...] Nie: istnieję, jestem, lecz: ukazuję się, jestem obrazem - look, look! Nie jest to już 
nawet przejaw narcyzmu, lecz pozbawiona wszelkiej głębi ekstrawersja, rodzaj reklamowej szczerości, dzięki której każdy staje się agentem własnego wyglądu” [Baurdillard 2009: 28] - pisze Baurdillard. Należy przy tym pamiętać, że każde odstępstwo od „normy” - próba w g l ą d u a nie o gląd u - może doprowadzić do emocjonalnych komplikacji, na które w płynnym miejskim życiu nie ma czasu.

Za dowód niech posłuży scena zbliżona do tej przedstawionej przed chwilą, uchwycona jednak przed „eksplozywnym momentem nowoczesności”. W Lalce naskórkowa, powierzchowna relacja czysto cielesna jest nie tylko niemożliwa z punktu widzenia konwenansu, lecz także niezadowalająca dla głównego bohatera.

W rozdziale siódmym, zatytułowanym Gołąb wychodzi na spotkanie węża [Prus 1998], obserwujemy Izabelę Łęcką, odwiedzającą sklep Wokulskiego pod pretekstem nabycia rękawiczek. Kobieta przeczuwa, że stała się dla kupca luksusowym towarem - „dla mnie ten sklep!” - myśli, i przekracza próg magazynu. Nie zakupy pchają ją jednak do wejścia w przestrzeń handlu, lecz chęć pokazania się i objęcia wzrokiem mężczyzny. W powieści czytamy: „Wejść do sklepu, spojrzeć w oczy Wokulskiemu i zapłacić mu za parę drobiazgów tymi właśnie pieniędzmi, które pochodziły od niego". Prowokacja - oto jedyne pragnienie Izabeli. Osiąga upragniony cel - po jej wejściu do sklepu młodzieniec oglądający laski „szybko uzbroił się w binokle” i „poprawił kołnierzyk na szyi”, „pan Lisiecki urwał w połowie swój okrągły frazes o stylu kandelabrów, ale zatrzymał okrągłą pozę”, a „dama słuchająca jego wykładu ciężko odwróciła się na krześle. Przez chwilę sklep zaległa cisza, którą dopiero panna Izabela przerwała.... Jej pojawienie się jest więc wystarczająco efektowne - wszystkie spojrzenia kierują się na nią, przestają się ślizgać po powierzchniach prezentowanych przez sprzedawców produktów, ogniskują się na „matrymonialnym towarze” (look, look!).

Izabela jest świadoma tej roli, w pewnym sensie sama się w nią wciela. Podejmuje z Wokulskim grę - demonstruje, że jest wiele warta w sensie estetycznym (wszyscy patrzą w jej stronę, nie ma w sklepie drugiego takiego produktu), a stając się uwodzicielska dla subiekta i wyniosła dla jego zwierzchnika, pokazuje, że to ona dyktuje warunki transakcji. Właściciel sklepu, pomimo posiadania dużego kapitału, nie 
zasłużył jeszcze na jej względy. By zdobyć taki towar jak ja - zdaje się mówić zachowanie Beli - musisz zapłacić (dać z siebie) więcej.

Związki erotyki i handlu są $w$ tym fragmencie niesłychanie silne. To, co je komplikuje, to wspomniana wyżej próba w g lą d u - Wokulskiemu nie wystarcza powierzchowna relacja z Łęcką, on chce ją r z e czyw iś ci e posiąść. Różnice w oczekiwaniach i metodach postępowania uniemożliwiają właściwe zdekodowanie swoich powierzchni. Wokulski, nieprzywykły do salonowych gier, jest rozdrażniony frywolnym zachowaniem kobiety. Izabela, przyzwyczajona do innego typu mężczyzn, nie rozumie metod właściciela sklepu, gardzi nim, a mimo to czuje "nieprzeparty pociag", ,widok tego człowieka wywiera na nią wpływ magnetyczny". Ich etykietki - rozpieszczonej arystokratki w błękitnej sukni i kupca z czerwonymi dłońmi - nie są kompatybilne. Nie ma tu mowy o sex appealu - jest nieudana transakcja wiązana.

Ma rację Bauman, pisząc, że zadanie, przed którym stanęły wolne jednostki po oswobodzeniu się ze „starych klatek” polega na tym, aby swą świeżo otrzymaną wolność wykorzystać do odszukania właściwej przegródki i usadowienia się w niej dzięki skrupulatnemu przestrzeganiu zasad i norm postępowania uznawanych za stosowne i właściwe dla tego miejsca [Bauman 2006: 13]. Wokulski i Izabela jeszcze się nie oswobodzili - żyją w mieście owładniętym „starymi” regułami. Spotykają się we wnętrzu - nie jest to już wprawdzie wnętrze salonu, wciąż jednak przestrzeń ograniczona, do wnętrza odsyłająca. Przejście ze sklepu do pasażu - najpierw „rzeczywistego”, a więc „miejsca pośredniego" między ulicą a wnętrzem, jednego z wynalazków przemysłowego luksusu, w którym „błyszczące emalią szyldy firm są równie dobre (a nawet lepsze) jako przystrojenie ścian, co obraz olejny w mieszczańskim salonie”, gdzie „kioski z gazetami służą za biblioteki, a kawiarniane tarasy to wykusze, $\mathrm{z}$ których po zakończonej pracy spogląda [się] na swój dobytek" [Benjamin 1996: 364-365], a następnie wirtualnego, w którym reprezentacja rzeczywistości jest standardem i miarą dla tej rzeczywistości, zakłada akceptację życia obok innych obcych i opanowanie reguł gry, umożliwiających nieinwazyjną koegzystencję; zgodę na bycie jednocześnie sprzedawcą (swojego wizerunku) i towarem (zachęcającym do obejrzenia go). Wejście w ponowoczesną „przegródkę 
miejską" oznacza tym samym umiejętność szybkiego dostrajania się do wymogów telemiasta (między innymi poprzez kształtowanie swojego „opakowania” na wzór modelu lansowanego w mediach), „czytania z siebie" - ze swoich powierzchni (etykiet); ocenę książki po okładce (bo na otwarcie jej nie ma czasu ani zgody samej książki). Etykietka - ta „prywatna powierzchnia reklamowa”, nasza osobista metka - label - jest więc istotą ponowoczesnej miejskiej atrakcyjności, piękna, doskonałości (la belle). Jej „wspaniałość” tkwi jednak, o czym należy pamiętać, w zaniku cech indywidualnych i zamknięciu na jedną, wybraną osobę (Iza-bela).

\section{Bibliografia}

Baudelaire C. [1998], Malarz życia nowoczesnego, Guze J. (przeł.), Słowo/ Obraz Terytoria, Gdańsk.

Baudrillard J [1994], Społeczeństwo konsumpcyjne, Królak S. (przeł.), Sic!, Warszawa.

Baudrillard J. [2009], Przejrzystość zła, Królak S. (przeł.), Sic!, Warszawa.

Bauman Z. [1994], Dwa szkice o moralności ponowoczesnej, Instytut Kultury, Warszawa.

Bauman Z. [1997], Wśród nas, nieznajomych - czyli o obcych w (po)nowoczesnym mieście, [w:] Pisanie miasta - czytanie miasta, Zeidler-Janiszewska A. (red.), Wydawnictwo Fundacji Humaniora, Poznań, s. 145-159. Bauman Z. [2006], Płynna nowoczesność, Wydawnictwo Literackie, Kraków. Bech H. [1999], Citysex. Representing Lust in Public, [w:] M. Featherstone, Love \& Eroticism, Sage Publications, Londyn, s. 215-243.

Benjamin W. [1996], Paryż II Cesarstwa według Baudelaire'a, [w:] Tegoż, Anioł historii, Krzemieniowa K., Orłowski H., Sikorski J. (przeł.), Wydawnictwo Poznańskie, Poznań, s. 71-117.

Benjamin W. [2005], Pasaże, Kania I. (przeł.), Wydawnictwo Literackie, Kraków.

Debord G. [2006], Społeczeństwo spektaklu oraz rozważania o społeczeństwie spektaklu, Kwaterko M. (przeł.), Państwowy Instytut Wydawniczy, Warszawa.

Joubert C., Stern S. [2006], Rozbierz mnie. Psychoanaliza garderoby, Biały B. (przeł.), Jacek Santorski \& Co Agencja Wydawnicza, Warszawa. 
Lu C. [2008], The Four Man Plan - A Romantic Science, Londyn.

Poe E.A. [1989], Opowiadania, Kopaliński W. (przeł.), Czytelnik, Warszawa. Prus B. [1998], Lalka, Ossolineum, Wrocław.

Simmel G. [1975], Mentalność mieszkańców wielkich miast, [w:] Tegoż: Socjologia, Łukasiewicz M. (przeł.), Państwowe Wydawnictwo Naukowe, Warszawa, 305-316.

Windsor S., Millar L., Szafa petna mężczyzn [2010], http://wiadomosci.onet. $\mathrm{pl} /$ kiosk/ciekawostki/szafa-pelna-mezczyzn,1,3354343, wiadomosc. html.

\section{Filmografia}

Seks w wielkim mieście, sezon 2., odc. 18. [1999], reż. D. Starr. 